\title{
LETTER
}

\section{Is non-invasive ventilation the best ventilatory support for 'do not intubate' patients?}

\author{
Guillaume Lacroix*1, Julien Legodec² ${ }^{2}$ Erwan D'Aranda', Pierre Esnault', Pierre-Emmanuel Romanat \\ and Philippe Goutorbe
}

See related letter by Scala and Esquinas, http://ccforum.com/content/16/3/429

We agree with the letter from Scala and Esquinas [1] in response to the article by Schortgen and colleagues [2], who emphasised the use of non-invasive ventilation in the ICU as the best ventilatory treatment for 'do not intubate' octogenarian patients. Scala and Esquinas argued that ICU beds are scarce and that the ICU environment alters contact between the patient and family.

We do not, however, entirely accept the views of Schortgen and colleagues. Use of the non-invasive ventilation mask for palliative care patients with acute respiratory distress prevents the patient from eating and talking, and the patient's experience can be that of being smothered. When the major indication is hypoxemia, a treatment option is the administration of high-flow oxygen using up to $60 \mathrm{l} /$ minute heated and humidified oxygen through a nasal cannula [3] The mouth is thus freed and the patient is able to eat and talk with his family. The cost to efficiency ratio is favourable because the Optiflow oxygenation system (Fischer and Paykel ${ }^{\mathrm{Tm}}$, Auckland, New Zealand) costs $€ 4,000$ versus $€ 15,600$ for the ${\mathrm{V} 60^{\circ}}^{\circ}$ ventilation system (Philips ${ }^{\mathrm{Tu}}$, Amsterdam, The Netherlands). Non-invasive ventilation appears preferable in chronic obstructive pulmonary disease patients with hypercapnia.

We tested high-flow oxygen administration in 10 'do not intubate' patients receiving palliative cancer care in whom a high oxygen concentration mask failed to relieve dyspnoea (abstract accepted for the Société Française
d'Anesthésie Réanimation National Congress, September 2012). The mean respiratory rate fell from 29 to 22 breaths/minute $(P<0.01)$ and the ability to communicate (visual analogue scale) increased from 2 to $7(P<0.01)$.

To conclude, high-flow oxygen is an easy and cheap way to relieve dyspnoea in 'do not intubate' patients.

\section{Competing interests}

The authors declare that they have no competing interests.

\section{Author details}

'Department of Anesthesiology and Intensive Care, Teaching Military Hospital Sainte Anne, Boulevard Sainte Anne, BP 20545, 83041 Cedex 09 Toulon, France. 2Pneumology Department, Teaching Military Hospital Sainte Anne, Boulevard Sainte Anne, BP 20545, 83041 Cedex 09 Toulon, France.

\section{Published: 8 August 2012}

\section{References}

1. Scala R, Esquinas A: Noninvasive mechanical ventilation for very old patients with limitations of care: is the ICU the most appropriate setting? Crit Care 2012, 16:429.

2. Schortgen F, Follin A, Piccari L, Roche-Campo F, Carteaux G, TaillandierHeriche E, Krypciak S, Thille AW, Paillaud E, Brochard L: Results of noninvasive ventilation in very old patients. Ann Intensive Care 2012, 2:5.

3. Roca O, Riera J, Torres F, Masclans J: High-flow oxygen therapy in acute respiratory failure. Respir Care 2010, 55:408-413.

doi:10.1186/cc11435

Cite this article as: Lacroix $\mathrm{G}$, et al: Is non-invasive ventilation the best ventilatory support for'do not intubate' patients? Critical Care 2012, 16:442.

\footnotetext{
*Correspondence: gllacroix@aol.com

'Department of Anesthesiology and Intensive Care, Teaching Military Hospital Sainte Anne, Boulevard Sainte Anne, BP 20545, 83041 Cedex 09 Toulon, France Full list of author information is available at the end of the article
} 